Doi: HTTPS://DOI.ORG/10.23910/2/2020.0381

\title{
Role of Non-Timber Forest Products in Rural Economy of Farmers
}

\author{
S. Singh ${ }^{1}$, N. Chaudhary ${ }^{2}$ and A. K. Bhatia ${ }^{3 *}$
}

Dr. Y S Parmar University of Horticulture and Agroforestry, Nauni, Solan, H.P. (177 001), India

\section{Corresponding Author}

A. K. Bhatia

e-mail: avinashgolu1997@gmail.com

\author{
Article History \\ Article ID: IJEP0381 \\ Received in $29^{\text {th }}$ August, 2020 \\ Received in revised form $13^{\text {th }}$ September, 2020 \\ Accepted in final form $20^{\text {th }}$ September, 2020
}

\begin{abstract}
Non-timber forest products (NTFPs), also known as non-wood forest products (NWFPs) and secondary forest products are useful substances obtained from forests. The key feature of NTFP's is the continuous flow of returns against timber returns that are available intermittently at an interval of rotation period. An estimated $80 \%$ of the population of the developing world uses NWFP to meet some of their health and nutritional needs. NTFPs provide greater opportunities to the people by providing employment in the lean agriculture season. Most of the activities pertaining to NTFPs like collection, processing, transportation, marketing etc. are labour intensive and provide employment. India holds monopoly in world trade over some of the natural resins and gums such as lac, gum karaya and guar gum. Tribals derive $20-40 \%$ of their annual income from minor forest produce on which they spend major portion of their time. It has been established that a number of tribal, rural and forest department communities derive a significant part of their needs, income food and nutrition. The edible NTFPs play an important role in food \& nutritional security of rural people. However, due to number of factors like destruction of natural habitat, fluctuating prices, population growth is hindering the development of NTFPs.
\end{abstract}

Keywords: Employment, forest, income, nutrition, timber

\section{Introduction}

Forests provide significant social and economic benefits at all level, especially in developing countries. Forest is an important renewable, natural resource, which greatly influences the socio-economic development in any rural community (Ghoshal, 2011). Economics of people living in forests has traditionally been dominated by subsistence agriculture. However, non-timber forest products play vital role among the tribal people and provide a source of subsistence, income and livelihood security (Peters et al., 1989; Hegde et al., 1996).

NTFPs are any product or service other than timber that is produced in forests. They include fruits and nuts, medicinal plants, gums, resins, fibres such as bamboo, grasses etc. These are also known as non wood forest products, minor forest produce and secondary forest products. NTFPs can provide an important means for economic growth, specifically to man-made resource poor and forest resource abundant geographical areas. NTFPs are another important feature of the continuous flow of returns against timber returns that are available intermittently at an interval of rotation period. NTFPs like fuel-wood, medicinal plants, wild edible vegetables, house building materials etc. are an important part of day-to-day livelihood activities, especially for tribal people (Sarmah et al., 2006). People from a wide range of socio-economic, geographical and cultural contexts harvest NTFPs for a number of purposes, including but not limited to household subsistence, maintenance of cultural and familial traditions, scientific learning and income (Kala, 2013). NTFPs provide important products for local, national and international markets. These markets are growing rapidly and steadily (Wilkinson and Elivitch, 2000). It is estimated that about 100 million people depend on NTFP for, food, shelter, medicine and cash income etc. At global level, more than two billion people are dwelling in forest, depending on NTFPs for subsistence, income and livelihood security (Vantomme, 2003). An estimated $80 \%$ of the population of the developing world uses NWFP to meet some of their health and nutritional needs (FAO, 2008). NTFPs are significant especially for poor, because they are available at low cost on common property lands. In a country like India, which has more than half of its population in rural areas and a large tribal population reliant on forest produce for their sustenance, NTFPs play a major role (Sawhney and Engel, 2003).

The importance of Non-Wood Forest Products (NWFPs) has been realized the world over. India is a pioneer in the field of NWFPs, owing to its rich biodiversity and use of different NWFPs from times immemorial. About 45,000 plant species are found in India, which is $12 \%$ of the global wealth of flowering plants. Of these, about 33\% are endemic (Jain, 
1987). About 3,000 plant species are of economic value in India.

Despite of huge importance, non-timber forest products are being depleted at an alarming rate and forest dependent communities continue to lose them, either through overexploitation or habitat destruction. Since the objective of NTFPs is to improve livelihoods and conservation of forest resources, these resources can best be assured through a process of gradual domestication in human-modified systems. Unless urgent measures are taken to reverse the current trend of harvesting NTFPs from the wild, most of these products will disappear before they are documented and the term NTFPs will eventually be a myth. However, there is the need for subdivision of the NTFPs continuum into natural, managed, and cultivated in order to enhance their research development, and promotion.

NTFPs are categorized into various types such as bamboos and canes, essential oils, tannins, fibres and flosses, medicinal plants, resins, animals and animals' products, fixed oils, miscellaneous products, gums and spices and condiments.

\section{Economic Importance of NTFPs}

- As a source of income: 10 to $70 \%$ of total income and 25 to $50 \%$ of their food requirements. In India, over 50 million people are dependent on NTFPs for their subsistence and cash income (Hegde et al., 1996)

- A source of revenue to forest department: Around $50 \%$ of forest revenues and $70 \%$ of forest based export income of the country comes from NTFPs. Thus it can be depicted that NTFPs form one of the mainstays of income and sustenance for many tribal communities (Rao, 1987; Gauraha, 1992; Chopra, 1993; Mallik, 2000). In last 5 years more than $70 \%$ of the revenue of Orissa Forest Department was contributed by NTFP.

- Rural livelihoods and alleviating the rural poverty

- International trade: At present, at least 150 NWFP are significant in terms of international trade, including honey, gum arabic, rattan, bamboo, mushrooms, resins, essential oils, and plant and animal parts for pharmaceutical products. Trade in NTFPs can act as an incentive for forest conservation by providing a source if income from resources that might otherwise appear to have little financial value.

- Employment opportunities: NTFPs provide greater opportunities to the people. Most of the activities pertaining to NTFPs like collection, plucking, processing, transport, marketing etc. are labour intensive and provide employment. NTFPs based small scale enterprises provide up to $50 \%$ of income for 20 to $30 \%$ of the rural labour force whereas $55 \%$ of the employment in forestry sector is attributed to the sector alone.

\section{Natural Resins, Gums (NRGS)}

Natural resins and gums originated from the plants/ insects may be classified in three categories: Natural resins, Natural gums and Gum resins. NRGs of commercial importance like lac (Kerria lacca Kerr), Pine resin, guar gum (Cyamopsis tetragonoloba L.), gum karaya (S. urens) and babool gum (Acacia nilotica) are produced in India. India holds monopoly in world trade over some of the NRGs such as lac, gum karaya and guar gum.

\subsection{World export aggregation of natural resins and gums} during 2015

Resins are used in the production of varnishes, adhesives and food glazing agents. These are also used as raw material for synthesis of incense and perfume. This group of natural resins includes lac secreted by an insect $K$. lacca (kerr) and plant originated products like rosin, copal and dammer. The world aggregation of export of natural resins and gums is present in Figure 1 and Table 1.

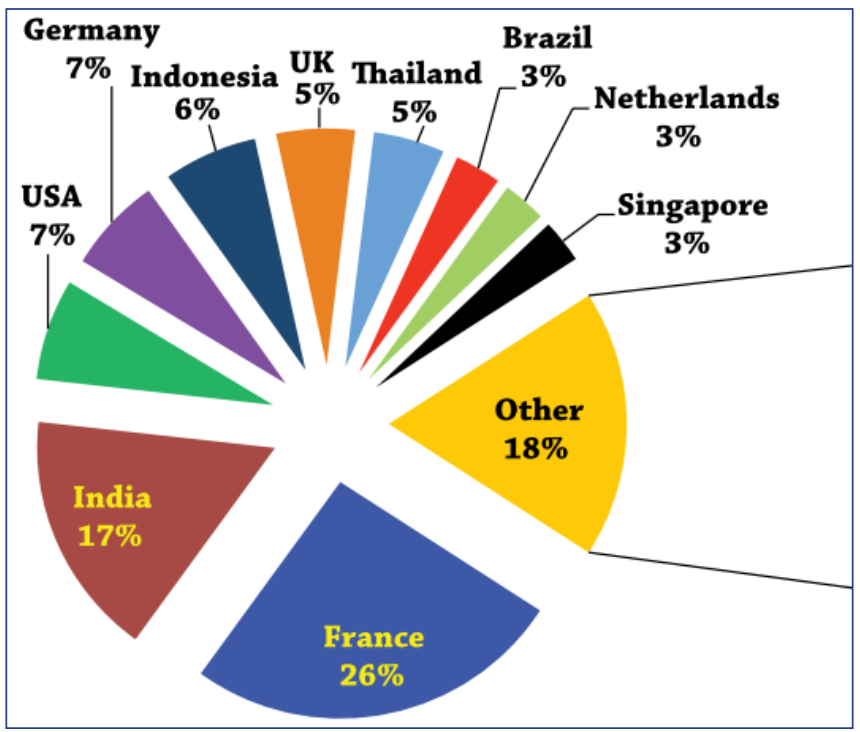

Figure 1: Export aggregation of natual resins and gums by different countries

Table 1: Total natural resins and gums production and trade during 2015-16 (in tone)

\begin{tabular}{lccc}
\hline Name of Product & Production & Export & Import \\
\hline Guar gum & 817042 & 256677.18 & 633.13 \\
Lac & 18746 & 7668.42 & 0 \\
Pine resin & 5726 & 204.33 & 41962.57 \\
Karaya gum & 100 & 230.79 & 771.56 \\
Other NRGs & 1563 & 7681.5 & 53020.39 \\
Total & 843178 & 272462.22 & 96387.65 \\
\hline
\end{tabular}

\section{Medicinal and Aromatic Plants}

India has been considered as treasure house of a large number of valuable medicinal and aromatic plant species. Ministry of Environment and Forests has identified and documented over 9500 plant species considering their importance in the 
pharmaceutical industry. MAP species are still by and large gathered and collected from the wild and relatively a few are cultivated in farmland. The exploitation from the nature coupled with increasing urbanization has led to steady erosion and loss of MAPs biodiversity from the natural habitat. It is therefore, relevant that these valuable plant species are not only preserved but also their cultivation practices are developed in order to meet the entire demand of the domestic industries as also to harness the bright prospect for current export.

- Medicinal plants are important in almost all the countries in the Asia.

- More than $80 \%$ of the population in the developing countries is believed to be dependent on medicinal plants for curing various diseases.

- The total trade in medicinal plants in India during 2004-05 has been 4,530 crore. In terms of the volume and value of medicinal plants exported, India ranks second in the world (Table 2).

\section{NTFP and India}

- According to World Bank estimates 275 million poor rural people in India (quoted in 'Down To Earth' Report, November 1-15 2010), depend on NTFPs for at least part of their subsistence and cash livelihoods.

- In India, NTFPs contribute an income equivalent to US\$ 2.7 billion per year and absorb 55\% of the total employment in forestry sector.

- They provide $50 \%$ of the household income for approximately one third of India's rural population.

- Moreover, $50 \%$ of forest revenues and $70 \%$ of forest based export income come from such resources.

- The states of Madhya Pradesh, Chhattisgarh, Orissa, Maharashtra and Andhra Pradesh account for more than $75 \%$ of traded NTFP in India.

\section{NTFP and Himachal Pradesh}

- The forests of Himachal Pradesh are rich in grasses and

Table 2: Country-wise status of export and import of MAPs

\begin{tabular}{lcclcc}
\hline Country of import & Quantity (tones) & Value [USS] & Country of export & Quantity (tones) & Value [USS] \\
\hline Hong Kong & 59,950 & $264,484,200$ & China & 150,600 & $266,038,500$ \\
USA & 51,200 & $139,379,500$ & Hong Kong & 55,000 & $201,021,200$ \\
Japan & 46,450 & $131,031,500$ & India & 40,400 & $61,665,500$ \\
Germany & 44,750 & $104,457,200$ & Mexico & 37,600 & $14,257,500$ \\
Rep. Korea & 33,500 & $49,889,200$ & Germany & 15,100 & $68,243,200$ \\
France & 21,800 & $51,975,000$ & USA & 13,050 & $104,572,000$ \\
China & 15,500 & $41,602,800$ & Egypt & 11,800 & $13,476,000$ \\
Italy & 11,950 & $43,006,600$ & Bulgaria & 10,300 & $14,335,500$ \\
Pakistan & 10,650 & $9,813,800$ & China & 9,850 & $26,352,000$ \\
Spain & 9,850 & $27,648,300$ & Morocco & 8,500 & $13,685,400$ \\
UK & 7,950 & $29,551,000$ & Albania & 8,050 & $11,693,300$ \\
Malaysia & 7,050 & $38,685,400$ & Singapore & 7,950 & $52,620,700$ \\
Total & 320,550 & $930,524,400$ & Total & 368,100 & $847,980,800$ \\
\hline
\end{tabular}

Source: COMTRADE database, United Nations Statistics Division, New York. (1991-2003)

other grazing plants, fiber, gum, resins, katha, medicinal and other herbs etc.

- Although non timber forest produce, have an important bearing on the life of rural population in the State, yet they have not been given due importance.

- The medicinal herbs from forests are considered as the chief component of non timber forest produce.

- The flora of Himachal Pradesh consists of 3300 species of plants. Of these, about 150 are attributed with medicinal value.

- Collection of these medicinal plants has been carried out by the local communities in Himachal Pradesh, since ancient times (Forests of Himachal Pradesh, 1993)

- Other non timber forest produce are katha extracted from khair, resin extracted from pines and cedar oil extracted from the deodar tree (Figure 2).

\section{Relation of NTFPs with Tribal Population}

Non-Timber Forest Produce (NTFPs) are of great significance in tribal life not only from the economic point of view but also from the Socio-cultural and religions point of view. The tribal people collect produces from forest such as firewood, fruit, roots, leaves, seeds, bulk, flowers, shrubs, herbs and mushrooms etc. for self consumption or sale in form of cash 


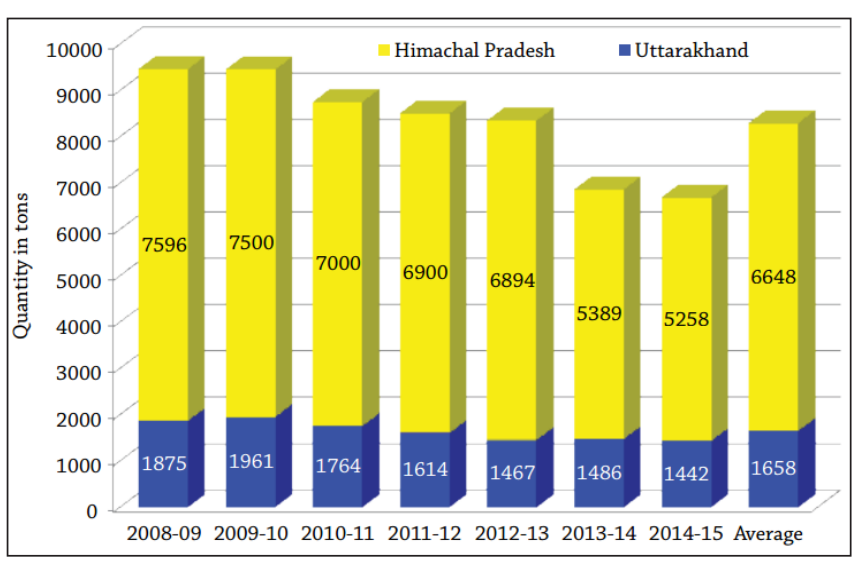

Figure 2: Pine resin production in Himachal Pradesh and Uttarakhand

or barter system. Forests have been regarded for the tribes as one of the sources of income and they support their standard of living from forests. It has been estimated that help of the employment generated in the forestry sector is through NTFP alone.

The contribution of MFP in the income of tribal households is:

- 5.4 to $13 \%$ in Orissa

- 7.4 to $14 \%$ in Bihar

- 13.6 to $39 \%$ in Madhya Pradesh

- 10 to $55 \%$ in Andhra Pradesh

The income realized in these states ranges from 5.4 to $55 \%$. Tribals derive $20-40 \%$ of their annual income from Minor Forest Produce on which they spend major portion of their time.

\section{Minimum Support Price Scheme}

Govt. of India introduced the scheme of "Mechanism for Marketing of Minor Forest Produce (MFP) through Minimum Support Price (MSP) and development of value chain" at the end of 2013-14. The scheme is designed as a social safety net for improvement of livelihood of MFP gatherers by providing them fair price for the MFPs they collect.

\section{Objectives:}

- To provide fair price to the MFP gatherers for the produce collected by them and enhance their income level.

- To ensure sustainable harvesting of MFPs.

- The Scheme will have a huge social dividend for MFP gatherers, majority of whom are tribal's.

- According to the guidelines issued for the implementation of the scheme, the Centre needs to provide $75 \%$ of the working capital in the form of revolving funds in the initial two years and share losses, if any, in the ratio of 75:25 between the Centre and the state.

- Initially, the scheme included 10 MFPs in 9 States. It was later expanded to 24 MFPs and in all States in 2017.
- The scheme also emphasizes the development of a value chain for MFPs, which includes creation of cold storage facilities, warehouses, processing units and modernization of haats (markets).

\section{Constraints in NTFPs Marketing}

- Unsustainable harvesting

- Old production technologies and methods

- Transportation facilities

- Fluctuating and lower prices

- Non availability of good market

- Commercialization in production of the NTFPs

\section{Conclusion}

It has been established that a number of tribal, rural and forest department communities derive a significant part of their needs, income food and nutrition. The edible NTFPs play an important role in f ood \& nutritional security of rural people. However, due to number of factors like destruction of natural habitat, fluctuating prices, population growth are hindering the development of NTFPs. They also contribute to the well-being of particularly the poor, in terms of food security, nutrition, health and subsistence. Management of forest resources in a sustainable way, improving harvesting and processing techniques are necessary for improving the livelihood of people and thus enhancing the use of NTFPs in a better way.

\section{References}

Chopra, K., 1993. The Value of Non-Timber Forest Products: Estimation for tropical deciduous forests in India. Economic Botany 47, 251-257.

FAO., 2008. Non Wood Forest Products, Rome, Italy.

Gauraha, A.K., 1992. Micro-economic analysis of a tribal village. Indian Journal of Agricultural Economics 47, 446-447.

Ghoshal, S., 2011. Importance of non-timber forest products in native household economy. Journal of Geography and Regional Planning 4, 159-168.

Hegde, R., Suryaprakash, S., Achoth, L., Bawa, K.S., 1996. Extraction of NTFPs in the Forests of B.R. Hills. Contribution to Rural Income. Economic Botany 50, 243.

Jain, S.K., 1987. Problems of endangered species: Study and solution. Presidential address, biological sciences, 57 session of national academy of sciences. Allahabad.

Kala, C.P., 2013. Harvesting and Supply Chain Analysis of Ethnobotanical Species in Pachmarhi Biosphere Reserve of India. American Journal of Environmental Protection 1, 20-27.

Mallik, R.H., 2000. Sustainable management of Non-Timber Forest Products in Orissa: Some issues and options. Indian Journal of Agricultural Economics 55, 384-397.

Peters, C.M., Gentry, A.H., Mendelssohn, R.O., 1989. Valuation 
of an Amazonian rainforest. Nature 339, 655-656.

Rao, G., 1987. Significance of minor forest produce in tribal economy: A case study, Kurukshetra. 7, 23-28.

Sarmah, R., Arunachalam, A., Majumder, M., Melkania, U., Adhikari, D., 2006. Ethno-medico-botany of Chakmas in Arunachal Pradesh, India. The Indian Forester 132, 474-484.

Sawhney, P., Engel, S., 2003. Importance of non-timber forest produce for subsistence and income generation in the life of local people. Case of Bandhavgarh National Park,
India. Centre for Development Research (ZEF), WalterFlex-Str. 3, 53113 Bonn.

Vantomme, 2003. Forest Products Division, Forestry Department, FAO, Rome.

Wilkinson, M.K., Elivitch, R.C., 2000. Non-Timber Forest Products for pacific islands: an introductory guide for producers. Agroforestry Guides for pacific Islands, Permanent Agriculture Resources, Holualoa, Hawaii, USA. 